\title{
The Research of the Training Mode of Innovation and Enterprise Capability of New Engineering Personnel in Local Colleges and Universities
}

\author{
Shao Defu \\ Jiamusi University \\ Heilongjiang, Jiamusi 154007
}

\author{
Ma Xiaojun* \\ Jiamusi University \\ Heilongjiang, Jiamusi 154007 \\ mjzx2009phd@163.com
}

\author{
Li Chunjiang \\ Jiamusi University \\ Heilongjiang, Jiamusi 154007 \\ jmslcj@sohu.com
}

\begin{abstract}
The research and practice of new engineering is the topical issue and research front in current higher engineering education field. "Fudan University Consensus", "Tianjin University Action" and "Beijing Guide" have constituted the "Trilogy" for the construction of new engineering. In February $20^{\text {th }}, 2017$, the Ministry of Education released the Notice of Carrying out the Research and Practice of New Engineering by Department of Higher Education in Ministry of Education and launched the "New Engineering Research and Practice" Project, which has brought new opportunities and challenges for local colleges and universities. Focusing on the fundamental task of morality education, local colleges and universities emphasis both of the morality and knowledge, who are continuing the researches and practice of new engineering and localizing and connecting with the regional development objective actively. Focused on the morality education and emphasizing both of the morality and knowledge, they have being stuck to marching towards the future, world and industry and improved the training mode of innovation and enterprise capability of new engineering personnel in local colleges and universities, as well as deepen the reform and innovation of higher engineering education, which have played a big backup role in regional economic environment and upgrade industries.
\end{abstract}

Keywords-local colleges and universities; new engineering; engineering personnel; innovation and entrepreneurship; training mode

\section{INTRODUCTION}

In February $20^{\text {th }}, 2017$, the Ministry of Education released the Notice of Carrying out the Research and Practice of New Engineering by Department of Higher Education in Ministry of Education and launched the "New Engineering Research and Practice" project. Therefore, research and practice concerns "new engineering" have been carried out in colleges and universities in our country. And the research and practice of new engineering is the topical issue and research front in current higher engineering education field. The research and

Funding Project: 2017 Heilongjiang education scientific planning key project: Innovation Ability Training Model Research of "New Engineering" College Students in Local Colleges and Universities.

*Correspondence Author: Ma Xiaojun(1976-), master tutor practice of new engineering are launched with the center topic of the new concept, new structure, new quality and new system of the reform on engineering education. "Fudan University Consensus", "Tianjin University Action" and "Beijing Guide" have pointed out the direction of the construction and development of new engineering. Under the background of the construction of new engineering, the reform of engineering education in local colleges and universities has faced opportunities and challenges. Focused on the morality education and emphasizing both of the morality and knowledge, they clearly know the school-running orientation. Centered on the development need of regional industry, they arranged the disciplines and specialty and broke the discipline barriers, as well as building school and region, school and enterprise, school and school community. Besides, they promoted the engineering education teaching reform and established the path of innovative engineering personnel training. Therefore, the training mode of innovation and enterprise capability of new engineering personnel under the innovative engineering education concept has been formed. The new concept, new structure, new quality and new system of the reform on engineering education have also been established. All these have played a big backup role in regional economic environment and upgrade industries. Based on "Fudan University Consensus”, “Tianjin University Action”, “Beijing Guide" and the document spirit of the Notice of Recommending New Engineering Research and Practice by the General Office of Ministry of Education, this paper focuses on how to enhance the foster abilities of new engineering personnel in local colleges and universities and provides the specific paths and methods of new engineering construction.

\section{DEEPLy INTEGRATING THE IDEOLOGICAL AND POLITICAL EDUCATION WITH NEW ENGINEERING PROFESSIONAL EDUCATION}

On the Ideological and Political Working Conference for National Universities and Colleges, Xi Jinping has emphasized 
that "the ideological and political work of colleges and universities concerns the basic problems of what kind of person should be cultivated by colleges and universities, how to cultivate person and whom should be cultivated for. Morality education should be continued as the central link. Ideological and political work should be run through the whole process of education and teaching, through which the whole-process education and all-directions education will be achieved." "The construction of teacher's ethics should be emphasized. Imparting knowledge and educating people should be continued to be unified. Teachers should be guided to live morally, learn morally and teach morally." The construction of new engineering in local colleges and universities should stick to a correct direction, which should focus on ideological education. Ideological and political education should be deeply blended with professional education in the following aspects, such as school-running orientation, service directions, and establishment of training program, curriculum setting, talent training standard and quality assessment standard. The fundamental task of morality education should also be emphasized. Ideological and political education should be deeply integrated with the second classroom. It is of use to deepen the classroom teaching reform and develop students' integrative capability quality and professional ability. The personnel training system of closely combining the first classroom and the second classroom should be perfected. It is also of use to carry out colorful extracurricular activities and cultivate students' professional quality, professional ability, innovation and enterprise capability and practical ability, as well as establish the scientific development view and make a good talent reserve for powerful nation through higher education.

\section{STRENGTHENING THE INNOVATIVE ENGINEERING EDUCATION CONCEPT AND PERFECTING THE INNOVATION AND ENTREPRENEURSHIP PERSONNEL TRAINING MODE}

Focus closely on the basic requirement of morality education, local colleges and universities have strengthened the innovative engineering education concept. The craftsmanship of "seeking increasing perfection and pursuing excellence" has been run through and integrated with the new engineering education all-dimensionally and deeply. Local colleges and universities has set the new engineering as the main line and highlighted the education characteristics of innovation and entrepreneurship in local comprehensive universities. Promote the whole-process and all-around innovation entrepreneurial ability training model of new engineering talents, which is based on platform and guided by innovative engineering education concept.

Taking innovation and entrepreneurship education as the core, local colleges and universities continuously perfecting the training mode of new engineering innovation and entrepreneurship. Firstly, system and mechanism has been perfected. "Creative thinking” has been stimulated. They adopt scientific and top-level design to excavate various education resources of innovation and entrepreneurship and complete institutional system to enhance the result of educating people through the innovation and entrepreneurship education. Secondly, multivariate cooperation has been promoted and the "innovation" of students has been guaranteed. The innovative practical ability of students has been enhanced through the eminent talent supply by the deep integration of industry and learning and the deep cooperation between school and region, school and enterprise as well as school and school. Thirdly, environment of incubation should be created, which may provide the "entrepreneurship" service for students. Innovation and entrepreneurship platforms, such as incubators, technology entrepreneurship practice base and hacker space should be established. It is essential to promote the deep integration of information technology and engineering education and innovate the engineering education methods, as well as enhance the quality of personnel cultivation.

\section{StREnGTHENING THE INTEGRATION AND DOCKING OF CiTY AND SCHOOL, AND REALIZING THE ECONOMIC GROWTH AND INDUSTRIAL UPGRADING}

In June, 2016, engineering education major certification system in our country has realized the international effective equivalence, which has provided a good opportunity for deepening the engineering education reform. Nowadays, our country has pursued the innovation-driven development and implemented major strategies, such as "One Belt And One Road”, "Made in China 2025" and "Internet +". Represented by new technology, new operational types, new mode and new industry, the new economy is advancing vibrantly, which has put forward higher request for engineering qualified scientists and technicians. Therefore, the engineering education reform is urgently needed to be speed up. Higher engineering education is not only the strategic support for industry great power, but also the inevitable requirement for the industry intellectualization development. Engineering colleges, especially engineering specialty in local universities has played a demonstration and radiation role in the economic development of the service area.

With a history of 70 years, Jiamusi University has absolute advantages in agriculture engineering, which has realized the deep integration of school and region and the innovation-driven development. Since its establishment, the university has been committed itself to cultivate the applicable talents with high qualities for this region and community who are possessing with “four capabilities", such as "capable of learning well, capable of going to the community, capable of being used and capable of staying longer". Based on "Three River", our university has being served Long River and faced the whole country, as well as adjusted to the economic and social development, especially met the requirements of applicable talents with high qualities whom are needed in the implementation of Heilongjiang "Five Planning”, “Ten Key Industries" and the construction of "Agricultural Equipment Intelligence in Three River Region”. Our university has provided more talents, intellectual support, excellent educational resources and services for the construction of Heilongjiang human resources and higher education powerful province, the revitalization of the old industrial base and the country's modernization.

Through the new engineering construction, our university has realized the economic growth mode which is changing from the regional resources-driving to innovation-driven and 
deepen the regional supply-side structural reform. Based on the regional economic development, our university has finished several aspects, such as perfected the school governance structure, established modern university system, extended school service function, met the regional development orientation and cultivated a new economic growth point positively. Jiamusi bears the traditional advantage in agricultural equipment manufacturing. Based on the Sanjiang Plain and the good opportunity of "Made in China 2025”, it further accelerates the manufacture and industrial upgrading of agricultural equipment, especially the large-scale agricultural equipment and perfects the research and development, manufacture, assorting of agricultural implements and the comprehensive service industrial system. Jiamusi also accelerates the matching of agricultural machinery, clustering development and constructs the national comprehensive agricultural machinery base. In the pro-environment and new material industry, such as environmental protection and energy saving and extra-high-tension cable, Jiamusi promotes the rising of strategic industry and accelerates the innovative development path, such as the scientific and technological incubator, science park and internet + agriculture.

\section{RECONSTRUCTING THE CURRICULUM SySTEM OF NEW ENGINEERING PERSONNEL INNOVATION AND ENTERPRISE CAPABILITY TRAINING}

Under the background of new engineering, universities has put innovation and entrepreneurship education into a strategic height of training of application-oriented graduate talents with an overall consideration. Innovation and entrepreneurship education curriculum has been scientifically set up and reasonably arranged. The teaching content, teaching method and specific practical operation procedure of optimizing the innovation and entrepreneurship education has been added. In the meanwhile, "embedded" curriculum system and related accessory institution measures which are beneficial to the innovation education has been established and improved. The guiding thought of "pointing to area, gradually launching” has being persisted. Based on the document spirit of Notice of Carrying out New Engineering Research and Practice by Department of Higher Education of Ministry of Education (Department of Higher Education of Ministry of Education Official Letters [2017] No.6), "carrying out new engineering reform and practice of local colleges and universities” has been combined with the actual condition of universities. In terms of engineering specialty, the reform and construction of innovation and entrepreneurship education curriculum system has been conducted. Through the experimental construction of typical cases, scientific and feasible innovation and entrepreneurship education personnel training mode has been constructed. Besides, the comprehensive education system of assembling the ideological and political education, classroom teaching, extracurricular practice, the second classroom, social practice, artistic practice, creative innovation, entrepreneurship simulation, pioneering instructions and consulting services has also been constructed.

Firstly, the general education of innovation and entrepreneurship should be launched to all the students by setting up three innovation and entrepreneurship general courses, such as Career Planning for College Students, Introductory Theory of Innovation and Entrepreneurship of College Students and College Student Vocational Counsel. Secondly, professional innovation and entrepreneurship education courses should be set up, through which the professional innovation and entrepreneurship ability of students will be trained. These courses are able to guide students to launch innovation and entrepreneurship practical activities combining their own specialty and broaden the employment space, as well as promote students' employability. Thirdly, innovation and entrepreneurship education public elective courses should also be set up, which is able to assist students who have potential and interest in innovation and entrepreneurship to expand and enhance their innovation and entrepreneurship abilities. Supports of innovation and entrepreneurship project application and incubation have been provided. Therefore, an in-depth innovation and entrepreneurship education curriculum system of "general education training- professional training-practice training” has been formed, which is effectively to improve the training quality.

\section{CHARACTERIZED BY INNOVATION AND ENTREPRENEURSHIP EDUCATION, CONTINUOUSLY Perfecting the New EngineEring Personnel Training SYSTEM}

Firstly, setting up the mechanism and emphasizing on the implementation. Innovation and entrepreneurship work should be powerful guaranteed. Universities have established innovation and entrepreneurship education leading group that is responsible for the innovation and entrepreneurship work. Office of educational administration is in charge of the daily management of students' innovation and entrepreneurship. The innovation and entrepreneurship education organization which is initiated by office of educational administration and jointly controlled and managed by youth league committee, admission and employment office, science and technology department, student work department, graduate faculty and each colleges. Innovation and entrepreneurship education supervision and inspection system should be established. Special supervision should be carried out regularly. And innovation and entrepreneurship education work should be put into practice.

Secondly, strengthening the faculty and enhancing the fusion. Innovation and entrepreneurship education should be forged ahead steadily. Based on the principle of taking the fulltime teacher as main and the combination of full-time and parttime teachers and through the methods of "combination of professional and non-professional”, “combination of working hours and spare time" and "combination of campus and off campus”, full-time teachers, pluralistic class advisers and instructors should be trained, whom are required to integrate the innovation spirit and entrepreneurship awareness into classes. They are also being supported to turn the scientific and technological achievements of innovation and entrepreneurship program and encouraged to lead students to conduct the innovation and entrepreneurship.

Thirdly, double driving and emphasizing the connotation. "Five-in-one" comprehensive innovation and entrepreneurship education system should be established. Universities deeply 
implement the strategy of innovation-driven development and promote innovation and entrepreneurship into a greater range, higher level and deeper degree. Universities should guarantee for employment and enhance the competitiveness of personnel training. In the process of revising the personnel training programs, innovation and entrepreneurship education curriculum system should be integrated. In the meanwhile, the proportion of practical teaching procedure should be enlarged. The deep integration of innovation and entrepreneurship education curriculum system and personnel training curriculum system will cover all majors without any blind spot. The "Fivein-one" comprehensive innovation and entrepreneurship education system which is combining the classroom teaching, the second classroom, public welfare practice, social practice and artistic practice has been established. The innovation and entrepreneurship courses, such as Cultivation of Innovation Ability, Entrepreneurship and Career Planning have been added. Through the practice teaching activities of each major, such as perceptual practice, off-campus internship, internship and practice teaching link in summer, the comprehensive quality, consciousness and ability of innovation and entrepreneurship of students will be cultivated. Therefore, the quality of personnel training will be promoted.

Fourthly, setting up a platform and urging the promotion. The practical effect of innovation and entrepreneurship is remarkable. Universities set up practice platforms zealously, such as competition, practice, projects and teams related to innovation and entrepreneurship and combine the innovation and entrepreneurship education with scientific researches. Teachers are encouraged to integrate scientific research project with innovation and entrepreneurship works. Multiple channels should be adopted to foster the innovation and entrepreneurship abilities of students. Students are encouraged to form teams and take part in various competitions. The quality of innovation and entrepreneurship is arduously enhanced, which has pushed the innovation and entrepreneurship work of the whole university into a new height.

Fifthly, setting up a system and emphasizing the service. The practical results of the guidance of innovation and entrepreneurship should be achieved. Combined with the actual condition, the university has gradually build a whole-process and all-around innovation and entrepreneurship educationbased and activities-based guide service system. It is guided by competition, with teams enhancing the fusion, projects causing promotion and base for the improvement.

\section{CONCLUSION}

Under the background of new engineering construction, the engineering education reform of local colleges and universities have met both opportunities and challenges, who should advance with the times and under the guidance of "Fudan University Consensus", "Tianjin University Action" and "Beijing Guide". They should continuously conduct the new engineering research exploration and practice and actively connect with the region development objectives. Focused on the morality education and emphasizing both of the morality and knowledge, they have being stuck to marching towards the future, world and industry and improved the training mode of innovation and enterprise capability of new engineering personnel in local colleges and universities, as well as deepen the reform and innovation of higher engineering education, which have played a big backup role in regional economic environment and upgrade industries. They are still making arduous efforts for building a powerful industrial country.

\section{REFERENCES}

[1] Ye Min, Qian Hui. The New Industry Formats and New Engineering [J]. Researches in Higher Education of Engineering, 2017, (04):5-9. [201709-04].(In Chinese)

[2] Shi Xiaoyan, Zhao Yan, Li Xiaokun. The Reflect on Confluent, Open and Self-adaptive New Engineering System in Local Colleges and Universities [J]. Researches in Higher Education of Engineering, 2017, (04):10-15. (In Chinese)

[3] Xia Jianguo, Zhaojun. Brief analysis on New Engineering Education Reform in Local Colleges and Universities under the Background of New Engineering Construction, [J/OL]. Researches in Higher Education of Engineering, 2017, (03): 15-19+65. (In Chinese)

[4] Zhong Denghua. The Connotation and Action of New Engineering Construction, [J/OL]. Researches in Higher Education of Engineering, 2017, (03): 1-6. (In Chinese)

[5] Hu Bo, Feng Hui, Han Weili, Xu Lei. The Review of Accelerating the Construction of New Engineering, Promoting the Engineering Education Reform and Innovation-“Seminar on Engineering Educational Development Strategy of Comprehensive Universities” [J]. Fudan Education Forum, 2017, 15(02):20-27+2(In Chinese)

[6] Wu Aihua, Hou Yongfeng, Yang Qiubo, Hao Jie. Accelerating the Development and Construction of New Engineering, Adapting to and Leading the New Economy Actively [J]. Researches in Higher Education of Engineering, 2017, (01): 1-9. (In Chinese) 